\title{
Strategy Use in Currency Conversion Tasks: The Examples of Euro into French Franc and French Franc into Euro Conversions
}

\section{P. Lemaire, M. Lecacheur and M. Ferréol-Barbey}

\author{
(2) OpenEdition \\ Journals \\ Electronic version \\ URL: http://journals.openedition.org/cpl/176 \\ DOI: $10.4000 / \mathrm{cpl} .176$ \\ ISSN: $1379-6100$ \\ Publisher \\ Centre PsyCLÉ
}

Printed version

Date of publication: 1 April 2001

\section{Electronic reference}

P. Lemaire, M. Lecacheur and M. Ferréol-Barbey, « Strategy Use in Currency Conversion Tasks: The Examples of Euro into French Franc and French Franc into Euro Conversions », Current psychology letters [Online], 2001/1, 4 | 2001, Online since 05 September 2003, connection on 08 September 2020. URL : http://journals.openedition.org/cpl/176 ; DOI : https://doi.org/10.4000/cpl.176

This text was automatically generated on 8 September 2020

(c) All rights reserved 
Strategy Use in Currency Conversion Tasks: The Examples of Euro into French Franc and French Franc into Euro Conversions

P. Lemaire, M. Lecacheur and M. Ferréol-Barbey 